\title{
PENERAPAN MODEL KOMUNIKASI INTERPERSONAL TERHADAP PENYEMBUHAN PASIEN (STUDI PADA RUMAH SAKIT ISLAM METRO DAN RSU MUHAMMADIYAH METRO)
}

\author{
Ahmad Muhajir \\ Institut Agama Islam Negeri (IAIN) Metro \\ Jl. Ki Hadjar Dewantara 15 A Kota Metro Lampung 34111 \\ ahmadmuhajir05@gmail.com \\ Nurkholis \\ Institut Agama Islam Negeri (IAIN) Metro \\ Jl. Ki Hadjar Dewantara 15 A Kota Metro Lampung 34111 \\ kholisn43@yahoo.com
}

\begin{abstract}
Abstrak
Care and healing patients in hospitals is not just a matter of medical care, more than that requires a holistic-comprehensive approach covering the spiritual aspects of patients. The importance of spiritual aspects in supporting the healing of patients cannot be negotiated anymore, because patients in hospitals, especially inpatients with acute illness not only suffer from various physical ailments but they also experience various stresses and spiritual mental disorders from mild to severe as the result of his illness. Patients who suffer from severe illness experience various anxieties, fears, as well as patients who will face surgery and post-surgery, patients who face critical moments such as facing death, dying, is not the realm of medical care issues alone, but it really needs assistance, services, and spiritual assistance. This study tries to apply a communication model carried out by spiritual guidance (Binroh) to patients in the Islamic Hospital and Muhammadiyah Metro Hospital. This research aims to determine the application of interpersonal communication models of spiritual guidance (binroh) at Islamic Hospital and Muhammadiyah Metro Hospital to the healing of patients, as well as the results achieved in the application of interpersonal communication in both hospitals.

This research uses a qualitative approach. Terminologically qualitative research is research that produces descriptive data in the form of written or oral words from people or observable behavior. Qualitative research methods seek to understand and interpret the meaning of an event in human behavior interactions in certain situations. Researchers in this case make direct observations in the process of fostering patients by spiritual staff in Islamic Hospital and Muhammadiyah Metro Hospital.
\end{abstract}

Key: Interpersonal Communication, healing patients. 


\section{A. Pendahuluan}

Ketika manusia hidup di dunia ini saling berinteraksi, tentu tidak terlepas dari komunikasi yang mereka gunakan sehari-hari. Manusia dengan komunikasi hampir tidak dapat dipisahkan satu sama lainya. Secara garis besar komunikasi adalah proses penyampaian pesan/informasi dari komunikator kepada komunikan melalui suatu media kemudian terjadinya feed back (respon/timbal balik). Komunikasi yang baik terjadi apabila antara komunikator dan komunikan mengerti dengan bahasa yang mereka gunakan sehingga meminimalisir terjadinya miss communication atau salah pengertian. Kehidupan manusia dalam menjalani segala aktivitasnya tentu memerlukan komunikasi, tanpa komunikasi manusia tidak mungkin dapat berinteraksi dengan orang lain untuk mendapatkan informasi ataupun menyampaikan suatu pesan/ide gagasannya. Misalnya dalam bidang pekerjaan, seorang dosen yang sedang mengajar mahasiswa di kelas untuk menyampaikan pelajaran ataupun sebaliknya mahasiswa yang ingin menyampaikan pendapatnya tentu mereka melakukan interaksi dengan cara berkomunikasi secara verbal dengan menggunakan bahasa yang sama, sehingga dapat dimengerti satu sama lainnya.

Ada beberapa macam bentuk komunikasi yang dilakukan oleh manusia dalam kehidupan sehari-hari, salah satunya adalah komunikasi interpersonal. Komunikasi ini dilakukan oleh seorang komunikan dengan yang lainnya, jadi pada dasarnya seluruh aktivitas/kegiatan yang dilakukan oleh manusia selalu menggunakan komunikasi sebagai interaksi unuk melangsungkan aktivitas tersebut. Maka dari itu, komunikasi merupakan suatu kebutuhan yang fundamental (sangat mendasar) bagi kehidupan manusia. Dengan demikian, mengingat sangat pentingnya peran komunikasi dalam kehidupan manusia, komunikasi perlu dipelajari dengan baik karena, komunikasi yang baik dapat digunakan oleh manusia sebagai skill untuk dapat mencari suatu pekerjaan, mencari teman/sahabat, mendapatkan pasangan hidupnya, dan sebagainya. Dengan demikian belajarlah untuk berkomunikasi yang baik dan terampil karena segalanya memerlukan komunikasi.

Berdasarkan hasil pra survey yang penulis lakukan, sebagian besar orang yang menderita penyakit yang kronis tidak bisa menerima keadaan yang saat ini sedang menimpanya, dan bahkan merasa putus asa, padahal optimisme dan motivasi itu sangat dibutuhkan oleh seorang pasien dalam proses penyembuhannya.

Komunikasi model interpersonal adalah salah satu model komunikasi yang digunakan di Rumah Sakit Islam Metro dan Rumah Sakit Umum Muhammadiyah Metro dalam pelaksanaan pembinaan rohani terhadap pasien. Pembinaan rohani tersebut dimaksudkan sebagai upaya dari pihak rumah sakit untuk membantu pasien dalam proses penyembuhan juga agar menambah optimis dan menambah motivasi seorang pasien dalam menjalani pengobatan dan kesembuhannya. Pembinaan rohani dilakukan oleh seorang rohaniwan 
dengan melakukan komunikasi secara langsung dengan pasien. Berdasarkan hal tersebut, peneliti tertarik untuk melakukan penelitian di rumah sakit tersebut, untuk mengetahui keefektifan serta keberhasilan komunikasi yang sudah dilakukan selama ini, adapun rumusan masalah dalam penelitian ini adalah : bagaimana penerapan model komunikasi interpersonal terhadap motivasi penyembuhan pasien di RS Islam dan RSU Muhammadiyah Metro dan bagaimana hasil yang dicapai terhadap motivasi penyembuhan pasien.

Penelitian ini menggunakan jenis penelitian kualitatif. Secara terminologis penelitian kualitatif adalah prosedur penelitian yang menghasilkan data deskriptif berupa kata - kata tertulis atau lisan dari orang - orang atau prilaku yang dapat diamati. Metode penelitian kualitatif berusaha memahami dan menafsirkan makna suatu peristiwa interaksi tingkah laku manusia dalam situasi tertentu. ${ }^{1}$ Penelitian kualitatif mencakup penggunaan subjek yang dikaji dan kumpulan berbagai data empiris, studi kasus, pengalaman pribadi, introspeksi dan visual yang menggambarkan saat-saat dan makna keseharian dan problematis dalam kehidupan seseorang. ${ }^{2}$ Peneliti dalam hal ini melakukan pengamatan secara langsung dalam proses pembinaan pasien oleh tenaga bina rohani di RS Islam dan RSU Muhammadiyah Metro.

Penelitian ini menggunakan dua sumber data yaitu data primer dan data skunder, adapun data primer adalah data yang diperoleh secara langsung (dari tangan pertama), yaitu data yang diperoleh dari binroh, pasien rumah sakit dan keluarga penunggu pasien, sementara data sekunder adalah data yang peneliti peroleh dari data yang sudah ada, seperti dokumen berupa buku, brosur, laporan, daftar pasien, jadwal kunjungan binroh, materi pembinaan, dan lain sebagainya.

Setelah data terkumpul, maka data tersebut dianalisis dengan menggunakan teknik analisis data kualitatif dengan metode berfikir induktif dan deskriptif analisis. Cara berfikir induktif berpijak pada fakta-fakta yang bersifat khusus, kemudian diteliti dan akhirnya ditemui pemecahan persoalan yang bersifat umum. ${ }^{3}$

Sedangkan deskriptif analisis yaitu prosedur pemecahan masalah diselidiki dengan menggambarkan atau melukiskan keadaan subyek atau obyek penelitian (seseorang, lembaga, masyarakat dan lain-lainnya) pada saat sekarang berdasarkan fakta-fakta yang tampak atau sebagaimana adanya. Metode deskriptif analisis juga dapat diartikan menuturkan yang ada, misalnya tentang situasi yang dialami suatu hubungan kegiatan, pandangan,

${ }^{1}$ Husnaini Usman dan Purnomo Setiadi Akbar, Metodologi Penelitian Sosial, (Jakarta: Bumi Aksara, 2004), h.81

2 Norman K Denzin dan Yvonna S.Lincon, Handbook Of Qualitatife Research, diterjemahkan oleh Dariyatno, Badrus Samsul Fata, Abi, John Rinaldi, (Yogyakarta; Pustaka Pelajar, 2009), h.2. 2010) h.21

${ }^{3}$ Mardalis, Metode Penelitian Suatu Pendekatan Proposal,(Jakarta : Bumi Aksara, 
kegiatan, sikap yang nampak atau satu proses yang sedang berlangsung, pengaruh yang sedang bekerja, kelainan yang sedang muncul, kecenderungan yang nampak, pertentangan yang meruncing dan sebagainya. ${ }^{4}$

\section{B. Pembahasan}

\section{Pengertian Komunikasi Interpersonal}

Yang dimaksud dengan komunikasi interpersonal adalah komunikasi yang dilakukan antar perorangan dan dilakukan secara intensif baik verbal maupun non verbal sehingga masing-masing bisa memahami satu dengan yang lain dan berinteraksi secara efektif. Komunikasi antar pribadi meliputi komunikasi yang terjadi antar pramuniaga dengan pelanggan, anak dengan ayah, dua orang dalam satu wawancara, termasuk antara pengamen jalanan baik dijalanan tempat mereka menjalankan profesinya maupun di tempat-tempat lain. ${ }^{5}$

Menurut Dedi Mulyana, komunikasi interpersonal adalah bahwa komunikasi interpersonal adalah komunikasi antara orang-orang secara tatap muka, yang memungkinkan masing-masing orang menangkap reaksi orang lain secara langsung baik secara verbal maupun non-verbal. ${ }^{6}$

Komunikasi interpersonal pada hakikatnya merupakan salah satu bentuk dari komunikasi pribadi. Komunikasi interpersonal adalah komunikasi antara orang-orang secara tatap muka, yang memungkinkan setiap pesertanya menangkap reaksi orang lain secara langsung, baik secara verbal maupun nonverbal. Komunikasi interpersonal sangat potensial untuk menjalankan fungsi instrumental sebagai alat untuk mempengaruhi atau membujuk orang lain, karena kita dapat menggunakan kelimat alat indera kita untuk mempertinggi daya bujuk pesan yang kita komunikasikan kepada komunikan kita. Sebagai komunikasi yang paling lengkap dan paling sempurna, komunikasi antarpribadi berperan penting hingga kapanpun, selama manusia masih mempunyai emosi. Kenyataannya komunikasi tatap-muka ini membuat manusia merasa lebih akrab dengan sesamanya,berbeda dengan komunikasi lewat media massa seperti surat kabar, televisi, ataupun lewat teknologi tercanggihpun. ${ }^{7}$

Hartley mengemukakan bahwa terdapat tujuh karakteristik yang dapat mendefinisikan komunikasi interpersonal, yaitu:

1) Adanya tatap muka. Komunikasi dengan menggunakan media akan menimbulkan banyak gangguan pada proses komunikasi itu sendiri;

${ }^{4}$ Lexy J Moleong, Metodologi Penelitian Kualitatif (Bandung : Remaja Rosda Karya, 2012, cet-ke 30) h.279

5 Joseph A DeVito, , "Essentials of Human Communication", ( Boston: Allyn \& Bacon, Boston, 2005). h.231

6 Deddy Mulyana, Ilmu Komunikasi: Suatu Pengantar, ( Bandung: PT. Remaja Rosdakarya. 2002)h.46

${ }^{7}$ Deddy Mulyana, Ilmu Komunikasi,.. h.73 
2) Melibatkan dua orang dengan peran yang berbeda;

3) Bersifat dua arah;

4) Melibatkan pembentukan dan pertukaran makna;

5) Adanya tujuan (intensi);

6)Merupakan proses yang sedang berlangsung. Tidak bisa diberikan batasan jelas mengenai awal dan akhir; dan

7) Berakumulasi seiring dengan waktu.

\section{Jenis-Jenis Komunikasi Interpersonal}

Terdapat beberapa jenis hubungan interpersonal, yaitu: ${ }^{8}$

a) berdasarkanjumlah individu yang terlibat;

b) berdasarkan tujuan yang ingin dicapai;

c) berdasarkan jangka waktu;

d) berdasarkan tingkat kedalaman atau keintiman.

Hubungan interpersonal berdasarkan jumlah individu yang terlibat, dibagi menjadi 2, yaitu hubungan diadik dan hubungan triad. Hubungan diadik merupakan hubungan atara dua individu. Kebanyakan hubungan kita dengan orang lain bersifat diadik. William Wilmot mengemukakan beberapa ciri khas hubungan diadik, dimana setiap hubungan diadik memiliki tujuan khusus, individu dalam hubungan diadik menampilkan wajah yang berbeda dengan 'wajah' yang ditampilkannya dalam hubungan diadik yang lain, dan pada hubungan diadik berkembang pola komunikasi (termasuk pola berbahasa) yang unik atau khas yang akan membedakan hubungan tersebut dengan hubungan diadik yang lain.

Sedangkan hubungan triad merupakan hubungan antara tiga orang. Hubungan triad ini memiliki ciri lebih kompleks, tingkat keintiman atau kedekatan anatar individu lebih rendah, dan keputusan yang diambillebih didasarkan voting atau suara terbanyak (dalam hubungan diad, keputusan diambil melalui negosiasi).

Hubungan interpersonal berdasarkan tujuan yang ingin dicapai, dibagi menjadi 2, yaitu hubungan tugas dan hubungan sosial. Hubungan tugas merupakan sebuah hubungan yang terbentuk karena tujuan menyelesaikan sesuatu yang tidak dapat dikerjakan oleh individu sendirian. Misalnya hubungan antara pasien dengan dokter, hubungan mahasiswa dalam kelompok untuk mengerjakan tugas, dan lainlain. Sedangkan hubungan sosial merupakan hubungan yang tidak terbentuk dengan tujuan untuk menyelesaikan sesuatu. Hubungan ini terbentuk (baik secara personal dan sosial). Sebagai contoh adalah hubungan dua sahabat dekat, hubungan dua orang kenalan saat makan siang dan sebagianya.

Hubungan interpersonal berdasarkan jangka waktu juga dibagi menjadi 2, yaitu hubungan jangka pendek dan hubungan jangka panjang. Hubungan

${ }^{8}$ Andi Nuraedah Nur, d.. Hubungan Interpersonal: Pengertian, Teori, Tahap, dan Faktor yang Mempengaruhi Hubungan Interpersonal. (Malang: 2009) h. 4 
jangka pendek merupakan hubungan yang hanya berlangsung sebentar. Misalnya hubungan antara dua orang yang saling menyapa ketika bertemu di jalan. Sedangkan hubungan jangka panjang berlangsung dalam waktu yang lama. Semakin lama suatu hubungan semakin banyak investasi yang ditanam didalamnya (misalnya berupa emosi atau perasaaan, materi, waktu, komitmen dan sebagainya). Dan karenainvestasi yang ditanam itu banyak maka semakin besar usaha kita untuk mempertahankannya.

Selain ketiga jenis hubungan interpersonal yang sudah dijelaskan di atas, masih terdapat satu lagi jenis hubungan interpersonal yang didasarkan atas tingkat kedalaman atau keintiman, yaitu hubungan biasa dan hubungan akrab atau intim. Hubungan biasa merupakan hubungan yang sama sekali tidak dalam atauimpersonal atau ritual. Sedangkan hubungan akrab atau intim ditandai dengan penyingkapan diri (self-disclosure). Makin intim suatu hubungan, makin besar kemungkinan terjadinya penyingkapan diri tentang hal-hal yang sifatnya pribadi. Hubungan intim terkait dengan jangka waktu, dimana keintiman akan tumbuh pada jangka panjang. Karena itu hubungan intim akan cenderung dipertahankan karena investasi yang ditanamkan individu di dalamnya dalam jangka waktu yang lama telah banyak. Hubungan ini bersifat personal dan terbebas dari hal-hal yang ritual.

\section{Komunikasi Interpersonal Yang Efektif}

Komunikasi interpersonal yang efektif menurut De Vito tergantung pada 7 kemampuan spesifik, yaitu :

\section{a. Openness}

Openness atau keterbukaan adalah kesediaan untuk membuka diri atau membagi informasi tentang diri sendiri yang biasanya dirahasiakan, dan juga kesediaan untuk mendengarkan pesan yang disampaikan oleh orang lain secara terbuka dan merespon dengan jujur.

b. Empathy

Empati adalah kemampuan untuk merasakan apa yang dirasakan orang lain berdasarkan sudut pandang orang tersebut. Kemampuan ini dapat membantu individu untuk mengerti apa yang dilalui oleh lawan bicaranya secara emosional.

\section{c. Positiveness}

Positiveness mengacu pada kemampuan dalam menggunaan pesan yang positif. Kemampuan ini ditunjukkan dengan memuji hal-hal positif yang dimiliki oleh lawan bicara dan mengekspresikan kepuasan dalam berkomunikasi dengannya, dengan cara tersenyum, menjaga kedekatan posisi tubuh pada saat berbicara, dll.

d. Immediacy

Immediacy mengacu pada kedekatan hubungan antara pembicara dan pendengar. Saat berkomunikasi individu menunjukkan ketertarikan, 
perhatian, dan perasaan senang terhadap lawan bicaranya, dengan cara berbicara secara terbuka, menggunakan nama lawan bicara, fokus pada pesan yang disampaikan, dan memberikan feedback verbal atau nonverbal yang sesuai.

e. Interaction management

Interaction management mengacu pada teknik dan strategi yang digunakan dalam berinteraksi secara interpersonal. Teknik dan strategi ini meliputi kemampuan untuk membagi waktu bagi lawan bicara untuk berbicara, menjaga agar komunikasi dapat berjalan dengan lancar, dan memastikan bahwa pesan verbal dan nonverbal yang disampaikan saling berkesinambungan.

f. Expressiveness

Expressiveness mengacu pada kemampuan dalam mengekspresikan pemikiran dan perasaan, meyakinkan lawan bicara untuk berkomunikasi dengan terbuka, dan memberikan feedback yang sesuai terhadap pesan yang disampaikan oleh lawan bicara. Hal ini dapat dicapai dengan menggunakan nada suara dan isyarat (bahasa tubuh dan ekpresi wajah) yang sesuai dengan isi pesan yang disampaikan, mengekspresikan pemikiran dan perasaan dengan kesadaran akan adanya perbedaan budaya, dan memberikan feedback secara verbal maupun nonverbal.

g. Other-orientation

Other-orientation meliputi perhatian yang penuh dan ketertarikan terhadap orang lain dan apa yang mereka katakan, serta kemampuan dalam mengadaptasikan pesan sesuai dengan budaya lawan bicara dan lingkungan dimana komunikasi tersebut terjadi. Kemampuan ini dapat ditunjukkan dengan sikap sopan dan perhatian terhadap lawan bicara, mengakui bahwa perasaan lawan bicara sesuai dengan pesan yang disampaikannya, menganggap kehadiran orang tersebut penting, dan memfokuskan perhatian pada pesan yang disampaikan oleh lawan bicara. ${ }^{9}$

Berdasarkan hal tersebut, apabila komunikasi yang dilakukan mau berhasil dan efektif, maka harus memperhatikan dan mengikuti tujuh komponen tersebut dengan baik.

\section{Tujuan Komunikasi Interpersonal}

Tujuan-tujuan komunikasi antarpribadi atau interpersonal dapat dilihat dari dua perspektif yaitu :10

a. Tujuan-tujuan yang dilihat sebagai faktor-faktor motivasi atau sebagai alasan mengapa kita terlibat dalam komunikasi antarpribadi. Dengan

\footnotetext{
${ }^{9}$ Joseph A DeVito, “Essentials of Human..h.250-251

${ }^{10}$ Fajar, M. Ilmu Komunikasi Teori dan Praktek Edisi Pertama. (Yogyakarta: Graha
} Ilmu : 2009) h. 80 
demikian komunikasi antarpribadi bias mengubah sikap dan prilaku seseorang.

b. Tujuan-tujuan yang dipandang sebagai hasil efek umum dari komunikasi antar pribadi. Dengan demikian sebagai suatu hasil dari komunikasi antarpribadi adalah kita dapat mengenal diri kita sendiri, membuat hubungan lebih baik, bermakna dan memperoleh pengetahuan tentang dunia luar.

Menurut Widjaja dalam bukunya, fungsi komunikasi antar pribadi atau komunikasi interpersonal adalah berusaha meningkatkan hubungan insani, menghindari dan mengatasi konflik-konflik pribadi, mengurangi ketidakpastian sesuatu, serta berbagai pengetahuan dan pengalaman dengan orang lain. ${ }^{11}$

Komunikasi interpersonal dapat meningkatkan hubungan kemanusiaan diantara pihak-pihak yang berkomunikasi. Dalam hidup bermasyarakat seseorang bisa memperoleh kemudahan dalam hidupnya karena memiliki pasangan hidup. Melalui komunikasi interpersonal juga dapat berusaha membina hubungan baik, sehingga menghindari dan mengatasi terjadinya konflik-konflik yang terjadi.

Seseorang berkomunikasi dengan orang lain tentu saja mempunyai tujuan tertentu. Adapun tujuan umum yang ingin dicapai dalam komunikasi interpersonal adalah:12

1) menyampaikan informasi;

2) berbagi pengalaman;

3) menumbuhkan simpati;

4) melakukan kerja sama;

5) menceritakan kekesalan atau kekecewaan;

6) menumbuhkan motivasi.

Adapun tujuan komunikasi interpersonal yang utama menurut Suranto adalah sebagai berikut: ${ }^{13}$

1) Menemukan diri sendiri

Komunikasi interpersonal memberikan kesempatan kepada kita untuk berbicara tentang apa yang kita sukai, atau mengenai diri kita. Dengan saling membicarakan keadaan diri, minat, dan harapan maka seseorang memperoleh informasi berharga untuk mengenali jati diri, atau dengan kata lain menemukan diri sendiri. Melalui komunikasi interpersonal pula kita dapat belajar bagaimana kita belajar menghadapi orang lain, apa kekuatan dan kelemahan kita, dan siapa yang kita sukai atau tidak.

2) Menemukan dunia luar

${ }^{11}$ Widjaja, W. Komunikasi dan Hubungan Masyarakat. ( Jakarta: Bumi Aksara: 2010)

${ }^{12}$ Purwanto, D. Komunikasi Bisnis Edisi Keempat.( Jakarta: Erlangga.2011) h. 27

${ }^{13}$ Suranto, Komunikasi Interpersonal.( Yogyakarta: Graha Ilmu. 2011) h.19-20 
Melalui komunikasi interpersonal kita dapat memahami lebih banyak tentang diri kita dan orang lain yang berkomunikasi dengan kita. Hal itu menjadikan kita memahami dunia luar, dan kita dapat lebih banyak mendapatkan informasi. Bahkan kepercayaan, kenyataan, sikap dan nilainilai kita secara tidak langsung dan tanpa sadar dipengarui lebih banyak oleh pertemuan interpersonal daipada oleh media atau pendidikan formal. 3) Membentuk dan menjaga hubungan yang penuh arti

Sebagian besar waktu kita digunakan untuk berkomunikasi secara interpersonal dengan orang lain. Hal ini dilakukan untuk menjaga dan membentuk hubungan sosial dengan orang lain. Hubungan yang demikian dapat membantu mengurangi kesepian dan depresi, menjadikan kita sanggup saling berbagi, dan pada umumnya membuat kita merasa lebih positif tentang diri kita.

4) Mempengaruhi sikap dan tingkah laku

Komunikasi interpersonal merupakan komunikasi yang paling efektif dan mempunyai pengaruh yang besar dalam merubah sikap seseorang. Dalam prinsip komunikasi, ketika pihak komunikan menerima pesan atau informasi, berarti komunikan telah mendapat pengaruh dari proses komunikasi. Sebab pada dasarnya, komunikasi adalah sebuah fenomena, sebuah pengalaman. Setiap pengalaman akan memberikan makna pada situasi kehidupan manusia, termasuk memberi makna tertentu terhadap kemungkinan terjadinya perubahan sikap. Misalnya seorang ayah menginginkan anaknya agar ada perubahan sikap dan perilaku agar anaknya meningkatkan intensitas belajarnya, dan mengurangi ketergantungan memainkan hand phone dan internet.

5) Untuk bermain dan kesenangan

Bermain mencakup semua aktivitas yang mempunyai tujaun utama adalah mencari kesenangan. Berbicara dengan teman mengenai aktivitas kita, berdiskusi, bercerita hal-hal ringan dan lucu, kegiatan komunikasi semacam itu dapat memberikan keseimbangan yang penting dalma pikiran yang memerlukan rileks dari semua keseriusan di lingkungan kita.

6) Untuk membantu (konseling)

Ada beberapa profesi yang memang mengandalkan kemampuan komunikasi interpersonal untuk menjalankan pekerjaannya, seperti seorang ahli psikologi. Kita semua juga pada umumnya berfungsi membantu orang lain dalam interaksi interpersonal kita sehari-hari. Misalnya seorang remaja curhat kepada sahabatnya mengenai putus cinta. Tanpa disadari bahwa tujuan melakukan curhat tersebut adalah untuk mendapatkan bantuan pemikiran sehingga didapat solusi yang terbaik. Contoh lain, seorang mahasiswa berkonsultasi dengan dosen pembimbing akademik tentang suatu mata kuliah yang sebaiknya diambil.

7) Mengungkapkan perhatian kepada orang lain 
Pada prinsipnya komunikasi interpersonal dimaksudkan untuk menunjukan adanya perhatian kepada orang lain dan untuk menghindari kesan dari orang lain sebagai pribadi yang tertutup, dingin dan cuek. Misalnya, seorang pemimpin bertanya kepada karyawannya mengenai kabar karyawannya, sebenarnya mungkin pemimpin tersebut tidak bermaksud mengorek jawaban dari karyawan mengenai keadaan diri dan kesehatannya secara, namun hal tersebut dilakukan untuk memberikan kesan positif kepada karyawan dan tentunya menjaga hubungan yang baik dengan karyawan tersebut.

\section{Motivasi Penyembuhan Pasien}

Motivasi merupakan istilah yang lebih umum daripada motif yang menunjuk kepada seluruh proses gerakan, termasuk situasi yang mendorong adanya dorongan yang timbul dalam diri individu, tingkah lku yang ditimbulkan oleh situasi tersebut dan tujuan atau akhir dari gerakan atau perbuatan. Motivasi mengacu kepada sebab atau mengapa seseorang melakukan suatu kegiatan. Motivasi tersebut dapat diuraikan menjadi :

a. Motivasi yang mendorong aktifitas pribadi yang di dalamnya mengandung dorongan keinginan yang bersifat organis (jasmaniah) dan psikologis (rohaniah), motivasi ini menuntut kepada pemuasan rohaniah seperti harga diri, status, dan rasa aman serta kebebasan dari segala tekanan dan sebagainya.

b. Motivasi kepada keamanan atau disebut security motive, motivasi ini dipandang perlu oleh ahli psikologi sebagai yang paling asasi. Motivasi ini mengandung keinginan-keinginan yang didasarkan atas kebutuhan seseorang untuk melindungi dirinya sendiri dari segala bentuk ancaman terhadap integritas dan stabilitas hidupnya. Manifestasinya adalah dalam bentuk penghindaran dari bahaya dan resiko, juga dalam sikap hati-hati atau waspada serta konservatif dan sebagainya. ${ }^{14}$

Penyembuhan merupakan sebuah proses atau cara perbuatan penyembuhan, dengan demikian motivasi penyembuhan merupakan suatu dorongan untuk melakukan perbuatan penyembuhan atau dengan kata lain mendukung seseorang untuk sembuh dari penyakit yang di deritanya. Adapun dukungan-dukungan untuk penyembuhan tersebut terdiri dari :

1) Dukungan Psikospiritual

Dukungan psikospiritual sangat penting bagi orang yang sakit, hal ini akan membantu pasien untuk tetap optimis dan berfikiran positif dalam menghadapi penyakitnya, dukungan psikospiritual itu meliputi :

a. Menjenguk orang yang sakit.

b. Menanyakan keadaan orang yang sakit.

${ }^{14}$ Arifin, Psikologi Dakwah, (Jakarta : Bumi Aksara, 2004) h. 48 
c. Memberi kalimat yang membangkitkan semangat orang yang sakit.

d. Menanyakan keinginan orang yang sakit.

e. Mendoakan dan minta didoakan oleh orang sakit. ${ }^{15}$

2) Dukungan Material

Di samping dukungan psikospiritual, dukungan material juga sangat dibutuhkan oleh seorang pasien, karena selama sakit pasien tidak dapat mencari biaya untuk keperluan dirinya dan keluarganya, sementara itu selain kebutuhan pokok, ia juga membutuhkan biaya untuk pengobatannya. ${ }^{16}$

\section{Penerapan model komunikasi interpersonal di RS Muhammadiyah dan RS Islam Metro}

Pelayanan bina rohani di RSU Muhammadiyah Metro merupakan salah satu bentuk layanan penunjang yang menjadi hak setiap pasien yang berobat. Secara struktur organisasi, maka pelayanan bina rohani berada di bawah komando Wakil Direktur III bidang Bina Rohani, Sumber Daya Insani, dan Pencitraan (Bindatra) yang dikepalai oleh Bapak Abdurrahim Hamdi, M.A. pembinaan rohani bagi pasien dilakukan dengan metode komunikasi interpersonal yaitu komunikasi yang dilakukan secara Intensif antara petugas bina rohani RSU Muhammadiyah Metro dengan pasien baik verbal maupun non verbal sehingga masing-masing bisa memahami satu dengan yang lain dan berinteraksi secara efektif.

Pelaksanaan bina rohani bagi pasien dilakukan berdasarkan SOP yang telah ditentukan oleh RS Umum Muhammadiyah. ${ }^{17}$ Materi yang menjadi panduan petugas binroh disiapkan dan disesuaikan sedemikian rupa dengan kebutuhan pasien secara umum seperti doa kesembuhan, motivasi untuk sembuh dari sakit, tata cara wudhu dan shalat ketika sakit, menguatkan aqidah dan tauhid kepada Allah subhanahuwata'ala, berbaik sangka kepada Allah dengan ujian sakit yang diberikan dan lain sebagainya. Dalam menyampaikan materi, petugas bina rohani RS Umum Muhammadiyah Metro bersifat fleksibel namun dituntut untuk jeli melihat kondisi dan kebutuhan pasien, "petugas binroh memang harus jeli melihat kondisi pasien, tidak ujug-ujug ngasih nasehat, wejangan.. pokoknya lihat dulu pasiennya..."18

Penerapan model komunikasi interpersonal di RS Umum Muhammadiyah Metro secara umum dilakukan dengan langkah - langkah berikut:

15 Aliah B Purwakania Hasan, Pengantar Psikologi Kesehatan Islami (Jakarta : Rajawali Pers, 2008) h.498

${ }^{16}$ Ibid.

${ }^{17}$ Panduan Pembinaan Karyawan RS Umum Muhammadiyah Metro tahun 2016

${ }^{18}$ Wawancara dengan Bapak Nurrohman, S.Pd, staf bina rohani RSU Muhammadiyah Metro, Rabu 1 Agustus 2018 


\section{Salam dan menampakkan wajah ramah}

Petugas bina rohani dengan pakaian khusus dan tanda pengenal khusus memasuki ruangan dengan data pasien yang diberikan oleh petugas jaga. Petugas mengucapkan salam dan bersalaman dengan pasien dan keluarga pasien. Selain termasuk syiar Islam, lafadz salam juga terkandung doa keselamatan, rahmat dan keberkahan dari Allah subhanahuwata'ala.

2. Menyapa

Setelah mengucapkan salam, petugas menyapa pasien dan keluarga pasien dengan ungkapan: "bagaimana kabarnya pak/bu? Sehat pak/bu? Atau terkadang dengan menggunakan bahasa daerah untuk lebih mengakrabkan dengan pasien sesuai dengan kemampuan bahasa petugas.

3. Menanyakan kondisi pasien

Petugas menanyakan kondisi pasien saat ini, sudah berapa lama menginap di rumah sakit, sakitapa yang diderita, sejauh mana penanganan atas penyakit yang diderita dan seterusnya. Pertanyaan- pertanyaan tersebut bersifat fleksibel, artinya melihat keadaan pasien. Ada beberapa pasien yang sudah sulit untuk berkomunikasi, atau enggan untuk berkomunikasi lebih banyak, maka dalam hal ini petugas harus jeli dengan melihat keadaan pasien.

4. Memberikan pembinaan rohani.

Setelah melakukan langkah-langkah tersebut diatas, maka petugas segera memberikan pembinaan terhadap pasien sesuai keadaan masing masing. Petugas memberikan nasihat-nasihat rohani guna menguatkan jiwa/psikologis pasien. Diantara nasihat yaitu sabar, ikhlas, berharap pahala disisi Allah, husnudzon kepada Allah, yakin dengan pertolongan Allah, menguatkan tauhid bahwa yang menyembuhkan adalah Allah. Pada akhir pembinaan, petugas mendoakan kesembuhan bagi pasien dan memberikan motivasi kesembuhan.

Secara umum, persepsi pasien terhadap petugas bina rohani di Rumah Sakit Umum Muhammadiyah Metro sangat baik.Seperti yang disampaikan oleh salah satu pasien yang bernama ibu Siti Rukayah, 56 tahun, asal Kota Metro menyampaikan bahwa program bina rohani sangat perlu bagi para pasien dan sangat bermanfaat.

Sedangkan menurut Bapak Muslihudin, S.Kom.I jika didapatkan pasien atau keluarganya tidak memberikan respon yang baik maka proses pembinaan lebih kepada do'a dan motivasi secukupnya. Dikatakan bahwa salah satu yang menjadi kendala bagi petugas bina rohani RSU Muhammadiyah Metro yaitu tidak/ belum difasilitasinya petugas binroh dengan seragam khusus yang menjadi identitas resmi petugas, dengan 'performance' tersebut akan menambah kepercayaan diri para petugas bina rohani di RSU Muhammadiyah Metro. 
Pada kondisi yang lain, terdapat pasien yang memberikan respon yang sangat baik terhadap pelaksanaan pembinaan rohani bahkan meminta agar ditambah kunjungan petugas binroh pada waktu - waktu berikutnya.

Menurut Bapak Garianto, M.Pd.I dalam pelaksanaan pembinaan ada beberapa kendala "ya tetap ada kendala yang dihadapi ketika kita laksanakan pembinaan yaitu sikap dari pasien dan" ${ }^{19}$ Sikap yang dimaksud disini yaitu penolakan halus baik dari pasien maupun dari keluarga pasien meskipun jumlahnya sangat sedikit. Penolakan dari pasien biasanya ditunjukkan melalui sikap seperti acuh, menunjukkan wajah yang tidak suka, membuang wajah, berpura-pura tidur, tidak menanggapi apa yang disampaikan. Adapun penolakan dari keluarga pasien tidak jauh berbeda dengan pasiennya. Menanggapi sikap yang kurang baik dari pasien dan keluarganya, maka tim bina rohani dituntut untuk pintar dan jeli melihat keadaan tersebut, pembinaan tetap dilaksanakan meski dengan durasi yang tidak terlalu lama. Selain itu, menurut Bapak Garianto, M.Pd.I hendaknya tim bina rohani ketika diawal pelaksanaan pembinaan agar menyebutkan posisi strategis seperti pengurus yayasan yang membawahi Rumah Sakit tersebut.

Berikutnya, kendala yang dihadapi yaitu terkait 'performance' tim bina rohani. Hal ini dimaksudkan bahwa tim bina rohani semestinya memiliki penampilan yang berwibawa dengan seragam dan identitas khusus resmi dari RSU Muhammadiyah Metro. Dengan demikian, akan semakin menambah tingkat kepercayaan diri tim bina rohani. Performance yang dimaksud diantaranya baju seragam dan kartu identitas. Selama ini di Rumah Sakit Muhammadiyah Metro, para tim bina rohani yang berstatus sebagai tenaga sukarelawan hanya dibekali kartu identitas tanpa baju seragam khusus, hal ini diakui cukup berpengaruh terhadap persepsi penerimaan pasien dan keluarganya.

"jelaslah kita ini akan merasa lebih percaya diri dengan perlengkapan khusus, misalnya baju seragam. Kalau di rumah sakit muhammadiyah di Jakarta dan Bandung, posisi bina rohani memiliki kedudukan yang sangat baik". ${ }^{20}$

Kendala berikutnya yaitu tidak sebandingnya jumlah petugas binroh dengan jumlah pasien. Saat ini, petugas binroh berjumlah 5 orang, setiap hari rata - rata ada 5 pasien baru rawat inap, setiap pasien memiliki hak pelayanan bina rohani minimal $1 x$ selama pasien rawat inap di RSU Muhammadiyah Metro.Terkait kendala ini, para petugas binroh memanfaatkan waktu dengan baik.

Dalam hal pelayanan pasien di RS Islam Metro, di samping memberikan pelayanan secara medis, juga diberikan pelayanan secara

${ }^{19}$ Garianto, Petugas Bina Rohani RSU Muhammadiyah Metro, wawancara pada hari Senin, 17 September 2018

${ }^{20}$ Muslihudin (petugas bina rohani RSU Muhamamdiyah Metro) wawancara pada hari Jum'at, 21 September 2018 
psikologis, yaitu dengan memberikan bimbingan kerohanian. Sebagaimana disampaikan oleh bagian humas RS Islam Metro, bahwa setiap pasien rawat inap mendapatkan fasilitas berupa bimbingan rohani. Bimbingan rohani diberikan minimal satu kali selama dalam proses pengobatan, atau bisa juga dua kali atau bahkan lebih jika dikehendaki oleh keluarga pasien. Seperti ketika terdapat pasien yang menderita penyakit yang kronis, akan menjalani operasi maupun ketika pasien dalam keadaan sakaratul maut. Adapun tugas dari petugas bimbingan rohani di RS Islam Metro yaitu :21

1) Membimbing doa pasien dan keluarga pasien.

Yaitu melakukan pembimbingan kepada pasien dan keluarga pasien tentang doa-doa agar diberikan kesembuhan, karena yang memberikan kesembuhan semua penyakit hanyalah Alloh SWT, sedangkan berobat hanyalah sebagai perantara saja.

2) Memotivasi pasien.

Yaitu senantiasa memberikan motivasi kepada seluruh pasien dan juga keluarga atau penunggu pasien, dengan cara memberikan nasihatnasihat tentang pentingnya pemikiran yang optimis akan sangat membantu percepatan kesembuhan pasien.

3) Mentalqinkan pasien yang sedang sakaratul maut atau koma.

Setiap pasien yang dalam kondisi koma atau sakaratul maut harus dituntun untuk senantiasa mengucapkan atau memperdengarkan kalimat-kalimat ilahiyyah, agar keimanan dan ke-Islaman nya senantiasa terjaga. Dalam hal ini petugas binroh menunggu pemberitahuan dari pihak rumah sakit, apakah keluarga memerlukan bantuan untuk mentalqinkan pasien tersebut atau hanya keluarga sendiri sudah cukup. Jikalau memang diperlukan, maka petugas binroh akan segera dipanggil.

4) Mengajak pasien dan keluarga pasien untuk senantiasa beribadah dan berdoa dan mengajari tata cara beribadah.

Kondisi pasien yang sedang merasakan sakit, sebagian merasa tidak perlu lagi beribadah seperti sholat, karena menganggap ada keringanan bagi orang yang sakit. Hal ini yang menjadi tugas seorang petugas binroh untuk mengarahkan pasien dan keluarga yang menunggu pasien bahwa sholat dan ibadah sholat itu harus dilakukan walaupun dalam kondisi sakit, kemudian petugas membimbing dan membantu pasien yang belum memahami tata cara sholat bagi pasien yang tidak mampu berdiri atau duduk, termasuk tata cara bersuci maupun bertayamum.

5) Memberikan kultum sesudah sholat dhuhur.

Setiap sholat dhuhur, bnayak keluarga pasien dan petugas rumah sakit yang berjamaah di mushola yang terletak di dalam rumah sakit. Hal ini

${ }^{21}$ Hasil wawancara dengan $\mathrm{Bu}$ Ratmi, Kepala Bagian Humas RS Islam Metro, 1 Agustus 2018 
kemudian dimanfaatkan untuk memberikan nasehat-nasehat keagamaan yang langsung disampakan oleh petugas binroh.

Adapun teknis pelaksanaan bimbingan rohani di RS Islam Metro yaitu, sebelum petugas binroh melakukan tugasnya, terlebih dahulu lapor ke bagian kepala ruangan untuk melaksanakan binroh sekaligus untuk melihat data pasien yang membutuhkan bimbingan. Setelah itu petugas binroh langsung menuju ke ruangan-ruangan pasien, adapun waktu bimbingan selama kurang lebih 5 sampai dengan 7 menit. Materi bimbingan sebagaimana arahan dari pimpinan rumah sakit yaitu memberikan nasehat kepada pasien untuk banyak-banyak berdoa agar diberikan kesembuhan, juga memberikan nasehat untuk selalu rajin dalam beribadah, selain memberikan nasehat, petugas binroh juga memberikan motivasi kepada pasien, bahwa kesembuhan itu datangnya dari Alloh swt, setelah meminum obat atau mendapat pengobatan berupa medis, maka berdoa dengan diiringi keyakinan bahwa penyakit yang diderita akan diberikan kesembuhan oleh Alloh swt.

Dalam proses pelaksanaan pembimbingan terhadap pasien di RS Islam Metro, terdapat beberapa kendala, diantaranya adalah :

1. Keluarga dan pasien merasa terganggu dengan kedatangan petugas binroh.

2. Keluarga merasa tidak perlu adanya pembimbingan dari binroh, karena yang diharapkan dari rumah sakita adalah pengobatan dari dokter atau perawat.

3. Kurangnya respon dari pasien dan keluarga penunggu pasien terhadap petugas.

Adapun manfaat yang dirasakan oleh pasien dan keluarga pasien, sebagaimana disampaikan oleh bapak Sugeng, 45 tahun, dari Nampirejo Batanghari, adanya pembimbingan rohani dari petugas binroh sangat berpengaruh terhadap motivasi pasien dan juga keluarga pasien, apalagi rumah sakit yang membawa nama Islam, sudah sangat wajar dan memang harus ada siraman rohani dari petugas kerohanian. ${ }^{22}$

Berdasarkan hasil observasi langsung yang peneliti lakukan di rumah sakit, tentang bagaimana proses komunikasi interpersonal yang dilakukan oleh petugas pembina rohani, sudah sesuai dengan pendapat De Vito, tentang komunikasi interpersonal yang efektif tergantung pada 7 kemampuan spesifik, yaitu :

1. Openness

Opennes yaitu keterbukaan, sebagaimana yang dilakukan oleh petugas binroh pada saat memberikan pembinaan, respon dari pasien cukup baik yaitu ketersediaan dari pasien untuk membagi informasi tentang dirinya, penyakit yang diderita, serta keluh kesah yang dirasakan. Pasien juga

${ }^{22}$ Wawancara dengan Bapak Sugeng, keluarga pasien, pada tanggal 28 September 
bersedia mendengarkan dengan baik nasehat-nasehat yang diberikan oleh petugas binroh.

2. Empathy

Empati adalah kemampuan untuk merasakan apa yang dirasakan oleh orang lain, sebagaimana yang dilakukan oleh petugas binroh dalam menerapkan komunikasi interpersonal menunjukkan rasa empatinya kepada setiap pasien yang dilakukan pembinaan, sehingga seolah petugas binroh dapat merasakan apa yang dirasakan oleh pasien, dengan demikian komunikasi yang efektif dapat dengan mudah terjalin.

3. Positiveness

Possitivenes adalah kemampuan dalam mengunakan pesan yang positif. Dalam hal ini petugas binroh berkomunikasi dengan pasien dengan cara yang baik, yaitu dengan memuji hal-hal yang positif yang dimiliki oleh pasien, dengan tersenyum, menunjukkan ekspresi kepuasan terhadap pasien, menjaga kedekatan jarak dengan pasien.

4. Immediacy

Immediacy yaitu kedekatan hubungan antara pembicara dan pendengar. Sebagaimana yang dilakukan oleh petugas binroh pada saat melakukan pembinaan dilakukan dengan menunjukkan ketertarikan, perhatian dan perasaan senang denga pasien, berbicara secara terbuka dan sering menyebut nama pasien tersebut. Petugas binroh juga selalu aktif memberikan feedback kepada pasien baik secara verbal maupun non verbal yaitu dengan menganggukkan kepala atau dengan isyarat yang lainnya.

5. Interaction management

Interaction management adalah Teknik dan strategi yang meliputi kemampuan untuk membagi waktu bagi lawan bicara untuk berbicara, menjaga agar komunikasi dapat berjalan dengan lancar, dan memastikan bahwa pesan verbal dan nonverbal yang disampaikan saling berkesinambungan. Hal ini juga sudah dilakukan oleh petugas binroh dalam melaksanakan tugasnya, karena tugas dari binroh memang memberikan pesan moral kepada pasien agar memiliki optomisme dan motivasi untuk sembuh.

6. Expressiveness

Expressiveness adalah meyakinkan lawan bicara untuk berkomunikasi dengan terbuka, dan memberikan feedback yang sesuai terhadap pesan yang disampaikan oleh lawan bicara. Hal ini juga sudah dilakukan oleh petugas binroh, yang berkomunikasi dengan menggunakan nada suara dan isyarat (bahasa tubuh dan ekpresi wajah) yang sesuai dengan isi pesan yang disampaikan, mengekspresikan pemikiran dan perasaan dengan kesadaran akan adanya perbedaan budaya, dan memberikan feedback secara verbal maupun nonverbal.

7. Other-orientation 
Other-orientation yaitu perhatian yang penuh dan ketertarikan terhadap orang lain dan apa yang mereka katakan, serta kemampuan dalam mengadaptasikan pesan sesuai dengan budaya lawan bicara dan lingkungan dimana komunikasi tersebut terjadi. Dalam hal ini petugas binroh melakukan pembinaan kepada pasien dengan menunjukkan sikap sopan dan perhatian terhadap lawan bicara, mengakui bahwa pasien selaku lawan bicara sesuai dengan pesan yang disampaikannya, menganggap kehadiran orang tersebut penting, dan memfokuskan perhatian pada pesan yang disampaikan oleh pasien.

\section{Dampak Penerapan Komunikasi Interpersonal Terhadap Pasien}

Komunikasi interpersonal melalui pembinaan rohani memiliki dampak psikologis yang nyata bagi pasien yaitu sebagai berikut:

a. Termotivasi dan tumbuh sikap optimis untuk sembuh

b. Merasa ikhlas dengan sakit karena bagian dari taqdir dan penghapus dosa

c. Merasa relax

d. Bertambah pengetahuan tentang fiqih sakit.

Penerapan komunikasi interpersonal yang dilakukan oleh petugas binroh dalam membimbing pasien dan sekaligus keluarga pasien mempunyai dampak yang sangat positif, terutama bagi pasien dan keluarga pasien, dampak tersebut dirasakan pada kondisi psikologis pasien, mengingat hampir setiap pasien mengalami kondisi psikologis yang sama, yaitu merasa putus asa, merasa pesimis bahwa penyakit yang dialaminya bisa sembuh, merasa bahwa keadaan yang sekarang dialaminya merupakan siksaaan atau azab dari Alloh dan masih banyak pemikiran negative lainnya yang dirasakan oleh pasien. Setiap pasien yang dirawat, kondisi psikologisnya mayoritas dalam keadaan labil dan bahkan tidak dapat terkontrol dengan baik, sehingga dalam keadaan yang seperti ini sangat dibutuhkan masukan atau nasehat agar psikologis pasien dapat terkontrol dan terarah, dalam hal ini peran seorang pembina rohani sangat-sangat membantu dan dibutuhkan oleh pasien. Adanya kondisi yang demikian dimanfaatkan dengan baik oleh para petugas binroh dengan menggunakan komunikasi interpersonal dengan para pasien dan keluarga pasien. Penggunaan komunikasi interpersonal sangat cocok dan sesuai digunakan untuk berinteraksi dengan para pasien dan juga keluarga yang sedang mengalami musibah. Dengan komunikasi interpersonal yang dilakukan, diharapkan apa yang menjadi espektasi petugas binroh dapat tersampaikan dengan baik dan langsung berdampak terhadap pasien dan keluarga pasien.

Berdasarkan hasil wawancara yang dilakukan peneliti terhadap beberapa pasien dan keluarga pasien, dapat dilihat bahwa adanya pembinaan rohani yang dilakukan oleh petugas binroh sangat berpengaruh 
positif terhadap kondisi psikologis pasien, terutama terhadap motivasi kesembuhan pasien serta membantu pasien untuk lebih tabah dalam menjalani atau merasakan penyakit yang selama ini diderita. Setelah pasien mendapatkan pembinaan, maka perasaan pasien yang sebelumnya labil, was-was, dan bahkan putus asa menjadi lebih tenang dan optimis. Disamping itu dalam hal tat cara beribadah dan berdoa pasien juga menjadi target petugas binroh, mengingat seseorang yang sedang sakit, kondisinya tidak memungkinkan melakukan ibadah terutama sholat seperti dalam keadaan sehat. Ada ketentuan-ketentuan khusus yang kadang pasien kurang atau bahkan tidak memahaminya, seperti tata cara tayamum dan sholatnya seseorang yang sedang dalam kondisi lemah berbaring. Dalam hal ini seoarng petugas binroh menjelaskan dan membimbing pasien agar dapat senantiasa beribadah dan juga berdoa kepada Alloh, mengingat kesembuhan dan kesehatan seseorang hanyalah Alloh swt yang menentukan.

\section{Simpulan}

Berdasarkan atas hasil penelitian dan analisa data yang sudah penulis lakukan, maka dapat diambil kesimpulan dari penelitian ini yaitu : Pembimbingan rohani yang dilakukan di RSU Muhammadiyah Metro dan RS Islam Metro dilakukan oleh beberapa petugas yang sesuai dengan bidangnya dengan menggunakan model komunikasi interpersonal. Komunikasi interpersonal yang diterapkan tersebut dirasakan sangat banyak manfaatnya bagi pasien, baik dalam proses penyembuhan dari segi kejiwaan maupun sebagai motivasi untuk meraih kesembuhan.

Model komunikasi interpersonal yang sering digunakan oleh petugas binroh di RSU Muhammadiyah Metro dan RS Islam Metro adalah komunikasi interpersonal model triad, yaitu komunikasi intensif yang dilakukan lebih dari 2 orang, yaitu petugas dengan pasien dan keluarga/ penunggu. Petugas memfokuskan menjalin komunikasi dengan pasien dan keluarga pasien/ penunggu untuk mengetahui informasi yang dibutuhkan dan melalukan pembinaan rohani. Jika pasien tampak sulit/enggan berkomunikasi, maka petugas menjalin komunikasi dengan keluarga/ penunggu. 


\section{DAFTAR PUSTAKA}

Andi Nuraedah Nur, d.. Hubungan Interpersonal: Pengertian, Teori, Tahap, dan Faktor yang Mempengaruhi Hubungan Interpersonal. (Malang: 2009)

Deddy Mulyana, Ilmu Komunikasi: Suatu Pengantar,

( Bandung: PT. Remaja Rosdakarya. 2002)

Fajar, M. Ilmu Komunikasi Teori dan Praktek Edisi Pertama. (Yogyakarta: Graha Ilmu : 2009)

Joseph A DeVito, , "Essentials of Human Communication", ( Boston: Allyn \& Bacon, Boston, 2005)

Husnaini Usman dan Purnomo Setiadi Akbar, Metodologi Penelitian Sosial, (Jakarta: Bumi Aksara, 2004)

Norman K Denzin dan Yvonna S.Lincon, Handbook Of Qualitatife Research, diterjemahkan oleh Dariyatno, Badrus Samsul Fata, Abi, John Rinaldi, (Yogyakarta; Pustaka Pelajar, 2009)

Purwanto. D. Komunikasi Bisnis Edisi Keempat. (Jakarta: Erlangga, 2011)

Suranto, Komunikasi Interpersonal. ( Yogyakarta: Graha Ilmu. 2011)

Widjaja, W. Komunikasi dan Hubungan Masyarakat. ( Jakarta: Bumi Aksara: 2010)

Winari Lestari Dan Rahmi Lubis, Hubungan Produktivitas Kerja Pada Karyawan Costumer Service Bank Tabungan Negara Medan, dalam Jurnal Psikologia, 2014, vol. 9, no. 1, 